\title{
Professionalization of Family Firms: Striking a Balance Between Personal and Non-Personal Factors
}

\author{
ZOLTÁN KÁRPÁTI* \\ *Corvinus University of Budapest, Institute of Management; \\ zoltan.karpati@uni-corvinus.hu
}

DOI: $10.14267 / 978-963-503-867-1 \_12$

\begin{abstract}
The amount of research on family businesses' analysis has increased significantly in recent years, thus showing the high importance of the topic. In most countries, family businesses occupy a prominent place in contributing to the economy with the added value they produce. However, less attention has been paid to the professionalization of family businesses and the exploration and presentation of the related literature. The professionalization of family business is a significant research concern in the entrepreneurship and governance literature. In the context of family businesses, professionalization initially meant nothing more than hiring an outside, non-family manager. For today, the content of professionalization has expanded, and a multidimensional model has evolved: a broader, deeper understanding has evolved, which involves other vital aspects such as developing formal control and human resource systems, decentralization of authority, formal strategic planning, or top-level activeness. This study aims to present the essential international literature on professionalization and provide a comprehensive overview of the studies published. The literature review mainly summarizes the results of the last twenty years and closely related articles. The paper follows the next logic; in the first part, the definition of professionalization is introduced along with its benefits and challenges. Then, based on the research methodology presented, the related empirical and theoretical studies are examined. In the end, the review summarizes the key findings in a table.
\end{abstract}

Keywords: family firms, professionalization, non-family CEO, multidimensional phenomena

Funding: The author is grateful for the financial support received from the Corvinus Center of Family Business. 


\section{Introduction}

Calls for professionalizing family firms have a long history since family firms were usually depicted as unprofessional or an outdated type of organization (Chandler, 1977). It is also a significant research concern in the entrepreneurship and governance literature (Zhang \& Ma, 2009). As an organization grows over time, more employees and managers are needed to manage the company. In terms of family businesses, early publications identified professionalization as nothing more than the recruitment of a non-family external CEO (see Klein \& Bell, 2007; Zhang \& Ma, 2009), but recent studies and articles (Stewart \& Hitt, 2012; Dekker, Lybaert, Steijvers, Depaire, \& Mercken, 2013; Dekker, Lybaert, Steijvers, \& Depaire, 2015) claimed that professionalization is, in fact, a multidimensional paradigm. It involves the recruitment of external managers and appears in creating formalized systems, be it financial control, management, or human resource systems (Gimeno \& Parada, 2014). This idea is also confirmed by Polat's (2020) study, which is based on theoretical analysis, considers the professionalization of family firms to be a broader concept that includes management structures in addition to hiring external managers, such as boards and councils, formal financial and human resource control mechanisms, or formal strategic planning.

Nonetheless, in most research, professionalization is still identified with recruiting one or more external managers, thus representing a narrow view. Hall and Nordqvist (2008) also address this paradox by stating that family managers are often seen as non-professional managers who have inherited their roles, regardless of their professional and educational background as well as their relationship with the business. And for non-family managers, apart from their experience and their relationship with the company, they seem professional by nature.

My study aims to give an overview of empirical and theoretical studies and present the professionalization of family firms by reviewing and summarizing the relevant international literature. Existing research suggests that family businesses differ in terms of their professionalization (Madison, Daspit, Turner, \& Kellermans, 2018); thus, the presentation of the topic can contribute to a deeper understanding of family business operation and heterogeneity and provide practice-oriented advice and experience for practicing family business leaders. 


\section{Theoretical background}

\section{Defining the phenomena of professionalization}

Professionalization of a firm in mainstream business literature refers to its evolution through its organizational life cycle and consists of applying complex management and organization systems. Such systems may be formal planning, regular scheduled meetings, formal training, performance appraisal systems, defined responsibilities, management development, and formal governance bodies and control systems (Flamholtz \& Randle, 2007). The authors' further addition was that professionalization should also include the transfer of decision-making authority to middle managers, the implementation of formal control systems, changes in decision-making mechanisms, and the organizational structure's possible conversion.

According to Stewart and Hitt (2012) the term professionalization has no ultimate, generally accepted meaning in scientific or public discourse. Based on the most straightforward approach, it means no more than the full-time employment of employees. With a simple addition for family businesses, professionalization means full-time employment and recruiting external, non-family employees, typically with managerial competence. In many publications dealing with family business research, professionalization does not mean more than that (see Gedajlovic, Lubatkin, \& Schulze, 2004; Chittoor \& Das, 2007; Klein \& Bell, 2007; Zhang \& Ma, 2009).

Based on Dekker et al. (2013, p. 84), it can be synthesized that professionalization as a phenomenon cannot be limited to the recruitment of external managers but is accompanied by (1) the development of effective corporate governance systems such as the establishment of boards and councils (Songini, 2006; Flamholtz \& Randle, 2007; Chrisman, Chua, De Massis, Minola, \& Vismara, 2016; Howorth, Wright, Westhead, \& Allcock, 2016), (2) management development as hiring external and non-family members (Songini, 2006; Lin \& Hu, 2007; Yildirim-Öktem \& Üsdiken, 2010; Stewart \& Hitt, 2012) (3) delegating control as a management function and decentralizing authorities (Chua, Chrisman, \& Bergiel, 2009), (4) developing formal financial control mechanisms (Songini, 2006; Flamholtz \& Randle, 2007; Chua et al., 2009; Hiebl \& Mayrleitner, 2019) and (5) the design of formal human resource systems (De Kok, Thurik \& Uhlaner, 2006; TsuiAuch, 2004; Dyer, 2006; Madison et al., 2018). 


\section{Benefits of professionalization}

"The issue of professionalizing a family business is one that most, if not all leaders of growing family firms must grapple with at some point" (Dyer, 1989, p. 233). Many authors argue that family businesses need to professionalize in order to weaken their traditional impediments like opportunism, altruism, or nepotism (Dyer 1989; Basco, 2013). Others claim that the reason for professionalization is the lack of formal governance mechanisms and professional managers (Martínez, Stöhr, \& Quiroga, 2007; Sciascia \& Mazzola, 2008; Randøy et al., 2009; Dekker et al., 2013).

Professionalization can lead to financial benefits and competitive advantage in the case of family firms. The research of Schulze, Lubatkin, Dino, and Buchholtz (2001) on a sample of 1376 U.S. family-owned companies found that family firms that developed formal corporate governance mechanisms performed better financially than those who have not developed such systems. Anderson and Reeb (2003) and Martínez, Stöhr, and Quiroga (2007) both found, comparing family and non-family firms listed on the stock market, that family firms outperform non-family firms when they professionalize their management and develop formal governance mechanisms.

According to Dyer (1989), there are three main reasons why a family firm could professionalize:

a) The family's lack of management knowledge: such knowledge may be marketing, finance, or accounting knowledge. As the business grows, it is unlikely that they will be able to delegate family members with the right skills for each key position so that they will need outside help.

b) Changing the family business's norms and values: unconditional love and worry within the family is often at odds with profitability and efficiency.

c) Preparation for the transfer of leadership, succession: in case of the founder's retirement who feels no one could take over the business, hiring an external CEO could be necessary.

As environmental and organizational complexity increases, it becomes necessary for a company to formalize responsibilities, especially the transfer of roles and duties for various activities to the managers responsible for each organizational department (Gnan \& Songini, 2003). In some cases, professionalization can be seen by family businesses as a strategic opportunity to gain a lasting competitive advantage (Chua, Chrisman \& Bergiel, 2009; Fang, Memili, Chrisman, \& Welsh, 2012) and to access resources more easily, improve their productivity and to embark on a growth path (Craig \& Moores, 2005; Chua et al., 2009). As a result of the professionalization process, diverse perspectives brought 
in by external or internal professional managers can help family businesses seize opportunities while managing the risks of the dynamic environment around them, paving the way for better strategy-making (Polat, 2020).

\section{Difficulties of professionalization}

Family businesses are often reluctant to hire an external - non-family - manager, given that many family business owners focus on maintaining control over their own business (Vandekerkhof, Steijvers, Voordeckers, \& Hendriks, 2011; Dekker et al., 2013; De Massis, Di Minin, \& Frattini, 2015). Preserving the family's socio-emotional wealth (SEW) and reducing agency costs may also play an important role in a family's reluctance to involve an external manager (De Massis et al., 2015; Fang, Memili, Chrisman, \& Penney, 2017). Involving an outside leader independent of the family is likely to reduce the family's control over strategic decisions (Gomez-Meija, Cruz, Berrone, \& De Castro, 2011). Even if family businesses are ready for the challenges of professionalization and choose to do it so through hiring an external manager, there may be a lack of adequate financial resources to attract and retain skilled professionals (Songini, 2006; Tsao, Chen, Lin, \& Hyde, 2009) and recognize the need to implement necessary structural changes within the company (Songini, 2006).

There are also cases where the founders themselves are the barrier to professionalization, not recognized in time (Németh \& Németh, 2018). The founder and the successor's goals and ideas may be common, but many conflicts may arise during implementation. Another boundary to professionalization is that family firms prefer to use informal control systems and processes (Daily \& Dollinger, 1992; Jorissen, Laveren, Martens, \& Reheul, 2002; Songini, Morelli, Gnan, \& Vola, 2015; Diéguez-Soto, Duréndez, García-Pérez-de-Lema, \& Ruiz-Palomo, 2016) because strong interpersonal relationships serve as a control mechanism and family members are reluctant to control, evaluate, and sanction each other (Dyer, 2006). 


\section{Research method}

This paper is based on the standard methodology of a literature review. A thorough literature review provides insights into the current issues of the research topic (Hart, 2018), pointing out what is new at the international level in academic circles. By searching for and reviewing the literature on the case, it is possible to summarize the topic and form research questions (Rowley \& Slack, 2004). Besides, a literature review also provides a factual basis for subsequent empirical research, revealing unknown areas to be explored (Webster \& Watson, 2002). A literature review is a step after collecting literature: the analysis, critical evaluation, and synthesis of journal articles and other scholarly works filtered and selected according to specific criteria and a given research question (Hart, 2018).

I applied a mixed methodology (Grant \& Booth, 2009) to search and process the literature. Firstly, I used a search by keywords, and then I used a targeted search based on the reference lists and the so-called snowball method. Based on my prior knowledge of the keyword search, I filtered for journal articles in the EBSCO, JSTORE, and Science Direct databases that have been published in the last twenty years and whose title, keywords, or abstracts included "family business" or "family firm", and the terms "professionalization" or "professional management" or "performance". From the obtained results, I filtered out the publications published in other non-business and management disciplines. After that, I selected based on additional professional and content aspects: I filtered out the studies that were not relevant to the examined topic based on their title and abstract. In my research, I studied a total of more than seventy related journals or articles published in handbooks. Some publications outside the period under study will also appear in my study. I have included them in the literature review due to their significance, more profound presentation, description of the topic, and the high level of their citation. 


\section{Results}

\section{The multidimensional model of professionalization}

The literature can be categorized into two main categories: content and process. There are a various number of articles whose authors define what professionalization is and deal with its content, what does professionalization mean, and what are the elements of it (e.g., Stewart \& Hitt, 2012; Dekker at al., 2013; Dekker et al., 2015), and those who deal with its drivers, and have a process point of view (e.g., Zhang \& Ma, 2009; Howorth et al., 2016). In this paper I focus on the content aspect and present the main results in that perspective.

Dekker and her colleagues (2013) wanted to examine the degree of professionalization in the case of family businesses. However, the theories set up so far did not define how professionalization could be measured. They concluded an exploratory factor analysis and identified five important elements as dimensions of professionalization: (1) the first is financial control systems, the extent to which family companies use elements such as budgeting, financial planning, and built performance measurement systems; 2) second is the participation of non-family members in corporate governance systems (Gedajlovic, Lubatkin, \& Schulze, 2004; Öktem \& Üsdiken, 2010), the ratio of family or non-family members, (3) human resource control systems as recruitment, selection and remuneration systems, (4) decentralization of responsibilities as delegation of decision making, and (5) top-level activeness, how actively the company's top management communicates its goals and values. To validate the identified dimensions, quantitative research was conducted on a 532-item Belgian family sample of small and medium-sized enterprises and using cluster analysis; the firms were classified into four clusters (Dekker et al., 2013).

In addition to contributing to the literature on professionalization related to family businesses, Dekker and her colleagues make findings applicable in practice. The professionalization of family businesses is necessary by hiring an external manager, but it is not sufficient and is not the only viable path. While retaining family leadership, a family business can achieve a higher level of professionalization through other dimensions, such as the design of formal corporate governance systems, the implementation of formal control systems, thus ensuring the objectivity and transparency of the company's operations.

Their research two years later, carried out on 523 Belgian family businesses, confirmed the dimensions identified. Their study concluded that if a family business wants to positively influence its performance through professionalization, it should reduce family 
participation in corporate governance systems and increase the use of formal human resource control systems to help the family overcome nepotism or family altruism (Dekker et al., 2015).

\section{Complementing the multidimensional model of professionalization}

Among the publications of recent years, we find more than one that acknowledged Dekker et al.'s (2013) definition of professionalization and its multidimensional nature but made further additions. In his study, Basco (2013) proposed to include two new elements related to the concept, (1) the orientation of decision-making and (2) the consequences of professionalization. In his argument, he points out that the orientation of decision-making needs to be included because the management dimension of professionalization must also take into account the relationship between family and business, as it is related to decisionmaking. The consequences of professionalization must be taken into account in the light of the extent to which the family successfully achieves its goals and tasks. This view is reinforced by Gimeno and Parada (2014) that professionalization is closely linked to decision-making, where senior executives face poorly structured problems and an uncertain dynamic environment in which they have to make decisions competing with time under tremendous pressure.

In their research on 249 Portuguese family businesses, Camfield and Franco (2019) confirmed the dimensions of professionalization defined by Dekker et al. and suggested adding three new dimensions: (6) family involvement in management systems in parallel with previous research (Dyer, 1989; Gnan \& Songini, 2003; Hall \& Nordqvist, 2008; Chrisman, Chua, Le Breton - Miller, Miller, \& Steier, 2018) the professionalization of a business does not begin with the recruitment of an external, professional manager, but with the training of family members who can also acquire the necessary skills, (7) the cultural aspects that are at least as important as financial aspects (Gnan \& Songini, 2009; Waldkirch et al., 2017; Polat, 2020) and (8) organizational development thus complementing the professionalization of family businesses into an eight-dimensional multidimensional model.

The following table summarizes the theoretical and practical dimensions of professionalization with the additions mentioned earlier (Dyer, 1989; Songini, 2006; Dekker et al., 2013; Basco, 2013; Gimeno \& Parada, 2014; Camfield \& Franco, 2019) and new explorations (Suess, 2014; Madison et al., 2018; Polat, 2020). The supplemented model incorporates the content dimensions of professionalization explored so far based on theoretical and empirical analyses. The previous multidimensional models deal with too 
many factors and mix content and process topics. Besides, they show a bias towards either personal or material factors. The innovation in this model is:

a) Clearly defined, only includes content factors,

b) Simplified because it classifies the dimensions into four types

c) Balanced, as soft and hard factors have the same emphasis.

Table 1 summarizes the main findings of the types and dimensions of professionalization. It contains the personal, management, and organizational conditions in one place and treat the cultural aspect separately as it is the mixture of the previous two. It contains not only the business but the borderline family factors as well.

Table 1: The types and dimensions of professionalization in family firms

\begin{tabular}{|c|c|c|}
\hline $\begin{array}{l}\text { Type of } \\
\text { professionalization }\end{array}$ & Dimensions & Authors \\
\hline \multirow{6}{*}{$\begin{array}{l}\text { Professionalization of } \\
\text { members, boards, and } \\
\text { employees }\end{array}$} & Professionalization of board & Dekker et al., 2013 \\
\hline & Professionalization of managers & Dekker et al., 2013 \\
\hline & Non-family involvement in management & Dekker et al., 2013 \\
\hline & Delegation and decentralization of authority & Dyer 1989; Polat, 2020 Dyer, \\
\hline & Training of non-family managers & 1989; Polat, 2020 \\
\hline & Professionalizing non-family employees & Dyer, 1989 \\
\hline \multirow{7}{*}{$\begin{array}{l}\text { Professionalization of } \\
\text { organizational } \\
\text { structure, processes, } \\
\text { and operations }\end{array}$} & Strategic planning & Songini, 2006; Polat, 2020 \\
\hline & Formal organizational and operational structure & Polat, 2020; \\
\hline & Formal control mechanisms & Songini, 2006; Dekker et al., \\
\hline & Organizational development & 2013 Camfield \& Franco, \\
\hline & The orientation of decision making & 2019 \\
\hline & Formal human-resource systems like compensation & $\begin{array}{l}\text { Basco, 2013; Gimeno \& } \\
\text { Parada, } 2014\end{array}$ \\
\hline & $\begin{array}{l}\text { incentive systems and performance appraisal } \\
\text { systems }\end{array}$ & Madison et al., 2018 \\
\hline \multirow{4}{*}{$\begin{array}{l}\text { Professionalization of } \\
\text { work environment and } \\
\text { organizational culture }\end{array}$} & Cultural aspects: & \multirow{4}{*}{$\begin{array}{c}\text { based on Camfield \& Franco, } \\
2019 ; \\
\text { Polat, } 2020\end{array}$} \\
\hline & Organizational culture & \\
\hline & Business culture & \\
\hline & Technology culture & \\
\hline \multirow{2}{*}{$\begin{array}{l}\text { Professionalization of } \\
\text { family's relationship } \\
\text { with the business }\end{array}$} & $\begin{array}{l}\text { Effective governance mechanisms like a family } \\
\text { council and a family constitution }\end{array}$ & $\begin{array}{l}\text { Dekker et al., 2013; Suess, } \\
\qquad 2014\end{array}$ \\
\hline & Succession plan & Polat, 2020 \\
\hline
\end{tabular}

Source: Own editing based on Polat (2020) 


\section{Discussion and recommendations}

We have seen that professionalization of family businesses is a complex, multidimensional phenomenon that cannot be identified solely by the family, reducing its participation in corporate governance by hiring external, non-family leaders. In the literature, professionalization as a concept has gone through a dynamic development, with the initial identification of only one external manager recruitment (Klein \& Bell, 2007; Zhang \& Ma, 2009) being replaced by a multidimensional extension of the phenomenon (Dekker et al., 2013; Gimeno \& Parada, 2014; Dekker et al., 2015; Camfield \& Franco, 2019; Polat, 2020). In my study, based on the most important works of the last twenty years of international literature, I presented the professionalization of family firms, the initial meaning of the concept, its expansion, and the impediments and impetuses of professionalization for family firms. Based on the relevant literature, I summarized in a table at the end of my study which are the main dimensions of professionalization.

There has not been a comprehensive literature review on the professionalization of family businesses before. Although my paper is not intended to detail the publications cited in full, I trust that by presenting and reviewing the phenomenon and providing a new, clearly defined, presentation of the dimensions and types of family firm's professionalization, I can provide a comprehensive picture for practicing leaders and professionals and all readers interested in family businesses. 


\section{References}

Anderson, R. C., \& Reeb, D. M. (2003). Founding-Family Ownership and Firm Performance: Evidence from the S\&P 500. The Journal of Finance, 1301-1328. https://doi.org/10.1111/1540-6261.00567

Basco, R. (2013). The family's effect on family firm performance: A model testing the demographic and essence approaches. Journal of Family Business Strategy, 4(1), 42-66. https://doi.org/10.1016/j.jfbs.2012.12.003

Brumana, M., Cassia, L., De Massis, A., Cruz, A. D., \& Minola, T. (2015). Transgenerational professionalization of family firms: the role of next generation leaders. In P. Sharma, N. Auletta, R.-L. DeWitt, M. J. Parada, \& M. Yusof, Developing Next Generation Leaders for Transgenerational Entrepreneurial Family Enterprises (pp. 99-126). Cheltenham: Edward Elgar Publishing Limited.

Camfield, C., \& Franco, M. (2019). Professionalisation of the Family Firm and Its Relationship with Personal Values. The Journal of Entrepreneurship, 28(1), 144-288. https://doi.org/10.1177/0971355718810291

Chandler, A. (1977). The visible hand: the managerial revolution in American business. Cambridge, Mass.:Belknap.

Chittoor, R., \& Das, R. (2007). Professionalization of Management and Succession Performance-A Vital Linkage. Family Business Review, 20(1), 65-79. https://doi.org/10.1111/j.1741-6248.2007.00084.x

Chrisman, J. J., Chua, J. H., De Massis, A., Minola, T., \& Vismara, S. (2016). Management processes and strategy execution in family firms: from "what" to "how". Small Business Economics, 47, 719-734. https://doi.org/10.1007/s11187-016-9772-3

Chrisman, J. J., Chua, J. H., Le Breton - Miller, I., Miller, D., \& Steier, L. P. (2018). Governance Mechanisms and Family Firms. Entreprenenurship Theory and Practice, 42(2), 171-186. https://doi.org/10.1177/1042258717748650

Chua, J. H., Chrisman, J. J., \& Bergiel, E. B. (2009). An Agency Theoretic Analysis of the Professionalized Family Firm. Entrepreneurship Theory and Practice, 355-372. https://doi.org/10.1111/j.1540-6520.2009.00294.x

Craig, J., \& Moores, K. (2005). Balanced Scorecards to Drive the Strategic Planning of Family Firms. Family Business Review, 105-122. https://doi.org/10.1111/j.17416248.2005.00035.x

Daily, C. M., \& Dollinger, M. J. (1992). An Empirical Examination of Ownership Structure in Family and Professionally Managed Firms. Family Business Review, 117-136.

De Kok, J.M.P., Uhlaner, L.M.\& Thurik, A.R. (2006), Professional HRM Practices in Family Owned-Managed Enterprises. Journal of Small Business Management, 44, 441-460. https://doi.org/10.1111/j.1540-627X.2006.00181.x

De Massis, A., Di Minin, A., \& Frattini, F. (2015). Family-Driven Innovation: Resolving the Paradox in Family Firms. California Management Review, 58(I.), 5-19. https://doi.org/10.1525/cmr.2015.58.1.5 
Dekker, J. C., Lybaert, N., Steijvers, T., Depaire, B., \& Mercken, R. (2013). Family Firm Types Based on the Professionalization Construct: Exploratory Research. Family Business Review, 81-99. https://doi.org/10.1177/0894486512445614

Dekker, J., Lybaert, N., Steijvers, T., \& Depaire, B. (2015). The Effect of Family Business Professionalization as a Multidimensional Construct on Firm Performance. Journal of Small Business Management, 53(2), 516-538. https://doi.org/10.1111/jsbm.12082

Diéguez-Soto, J., Duréndez, A., García-Pérez-de-Lema, D., \& Ruiz-Palomo, D. (2016). Technological, management, and persistent innovation in small and medium family firms: The influence of professionalism. Canadian Journal of Administrative Sciences, 33, 332-336. https://doi.org/10.1002/cjas.1404

Dyer, W. J. (1989). Integrating Professional Management into a Family Owned Business. Family Business Review, 221-236.

Dyer, W. J. (2006). Examining the "Family Effect" on Firm Performance. Family Business Review, 19(4) 253-273. https://doi.org/10.1111/j.1741-6248.2006.00074.x

Fang, H., Memili, E., Chrisman, J. J., \& Penney, C. (2017). Industry and Information Asymmetry: The Case of the Employment of Non-Family Managers in Small and Medium-Sized Family Firms. Journal of Small Business Management, 55(4), 632-648. https://doi.org/10.1111/jsbm.12267

Fang, H., Memili, E., Chrisman, J. J., \& Welsh, D. H. (2012). Family Firm's Professionalization: Institutional Theory and Resource-Based View Perspectives. Small Business Institute Journal, 8(2), 12-34.

Flamholtz, E. G., \& Randle, Y. (2007). Growing Pain - Transitioning from an Entrepreneurship to a Professionally Managed Firm. San Fransisco: Jossy-Bass.

Gedajlovic, E., Lubatkin, M. H., \& Schulze, W. S. (2004). Crossing the Threshold from Founder Management To Professional Management: A Governance Perspective. Journal of Management Studies, 899-912. https://doi.org/10.1111/j.1467-6486.2004.00459.x

Gimeno, A., \& Parada, M. J. (2014). Professionalization of the family business: decision-making domains. In P. Sharma, P. Sieger, R. S. Nason, A. C. González L., \& K. Ramachandran, Exploring Transgenerational Entrepreneurship - The Role of Resources and Capabilities (pp. 42-62). Cheltenham: Edward Elgar Publishing Limited.

Gnan, L., \& Songini, L. (2003). The Professionalization of Family Firms: The Role of Agency Cost Control Mechanisms. FBN Proceedings.

Gnan, L., \& Songini, L. (2009). Women, Glass Ceiling, and Professionalization in Family SMEs. A Missed Link. Journal of Enterprising Culture, 497-525. https://doi.org/10.1142/s0218495809000461

Gomez-Meija, L. R., Cruz, C., Berrone, P., \& De Castro, J. (2011). The Bind that Ties: Socioemotional Wealth Preservation in Family Firms. The Academy of Management Annals, 5(1), 653-707. https://doi.org/10.5465/19416520.2011.593320

Grant, M. J., \& Booth, A. (2009). A typology of reviews: An analysis of 14 review types and associated methodologies. Health Information and Libraries Journal, 26(2), 91-108. https://doi.org/10.1111/j.1471-1842.2009.00848.x 
Hall, A., \& Nordqvist, M. (2008). Professional Management in Family Businesses: Toward an Extended Understanding. Family Business Review 21(1), 51-69. https://doi.org/10.1111/j.1741-6248.2007.00109.x

Hart, C. (2018). Doing a Literature Review: Releasing the Research Imagination (SAGE Study Skills Series). London: Sage Publications.

Hiebl, M. R., \& Mayrleitner, B. (2019). Professionalization of management accounting in family firms: the impact of family members. Review of Managerial Science, 13(5), 1037-1068. https://doi.org/10.1007/s11846-017-0274-8

Howorth, C., Wright, M., Westhead, P., \& Allcock, D. (2016). Company metamorphosis: professionalization waves, family firms and management buyouts. Small Business Economics, 47(3), 803-817. https://doi.org/10.1007/s11187-016-9761-6

Jorissen, A., Laveren, E., Martens, R., \& Reheul, A.-M. (2002). Differences Between Family and Non-Family Firms - The impact of different research samples with increasing elimination of demographic sample differences. Working Papers.

Klein, S. B., \& Bell, F.-A. (2007). Non-Family Executives in Family Businesses - A Literature Review. Electronic Journal of Family Business Studies 1(1), 19-37.

Lin, S.-h., \& Hu, S.-y. (2007). A Family Member or Professional Management? The Choice of a CEO and Its Impact on Performance. Corporate Governance: An International Review, 15, 1348-1362. https://doi.org/10.1111/j.1467-8683.2007.00650.x

Madison, K., Daspit, J. J., Turner, K., \& Kellermans, F. W. (2018). Family firm human resource practices: Investigating the effects of professionalization and bifurcation bias on performance. Journal of Business Research, 84, 327-336. https://doi.org/10.1016/j.jbusres.2017.06.021

Martínez, J. I., Stöhr, B. S., \& Quiroga, F. B. (2007). Family Ownership and Firm Performance: Evidence From Public Companies in Chile. Family Business Review 20(2), 83-94. https://doi.org/10.1111/j.1741-6248.2007.00087.x

Németh, K., \& Németh, S. (2018). Professzionalizálódó családi vállalkozások Magyarországon. Prosperitas Vol. V., (24-47.). https://doi.org/10.31570/prosp_2018_03_2

Öktem, Ö. Y., \& Üsdiken, B. (2010). Contingencies Versus External Pressure: Professionalization in Boards of Firms Affiliated to Family Business Groups in LateIndustrializing Countries. British Journal Of Management, 21(1), 115-130. https://doi.org/10.1111/j.1467-8551.2009.00663.x

Polat, G. (2020). Advancing the multidimensional approach to family business professionalization. Journal of Family Business Management. https://doi.org/10.1108/jfbm-03-2020-0020

Randøy, T., Dibrell, C., \& Craig, J. B. (2009). Founding Family Leadership and Industry Profitability. Small Business Economics, 32(4), 397-407. https://doi.org/10.1007/s11187008-9099-9

Rowley, J. \& Slack, F. (2004). Conducting a literature review. Management Research News, $27(6), 31-39$. 
Schulze, W. S., Lubatkin, M. H., Dino, R. N., \& Buchholtz, A. K. (2001). Agency Relationships in Family Firms: Theory and Evidence. Organization Science, 12(2), 99-116. https://doi.org/10.1287/orsc.12.2.99.10114

Sciascia, S., \& Mazzola, P. (2008). Family Involvement in Ownership and Management: Exploring Nonlinear Effects on Performance. Family Business Review, 21(4), 331-345. https://doi.org/10.1177/08944865080210040105

Songini, L. (2006). The professionalization of family firms: theory and practice. In P. Z. Poutziouris, K. X. Smyrnios, \& S. B. Klein, Handbook of Research on Family Business. Cheltenham: Edward Elgar Publishing Limited. https://doi.org/10.4337/9781847204394.00026

Songini, L., Morelli, C., Gnan, L., \& Vola, P. (2015). The Why and How of Managerializati on of Family Businesses: Evidences from Italy. Rivista Piccola Impresa/Small Business, 86118.

Suess, J. (2014). Family governance - Literature review and the development of a conceptual model. Journal of Family Business Strategy, 5(2), 138-155. https://doi.org/10.1016/j.jfbs.2014.02.001

Stewart, A., \& Hitt, MA. (2012). Why Can't a Family Business Be More Like a Nonfamily Business?: Modes of Professionalization in Family Firms. Family Business Review, 25(1), 58-86. doi:10.1177/0894486511421665

Tsao, C.-W., Chen, S.-J., Lin, C.-S., \& Hyde, W. (2009). Founding-Family Ownership and Firm Performance: The Role of High-Performance Work Systems. Family Business Review 22(4), 319-332. https://doi.org/10.1177/0894486509339322

Tsui-Auch, L. (2004). The Professionally Managed Family-ruled Enterprise: Ethnic Chinese Business in Singapore. Journal of Management Studies, 41(4), 693-723. https://doi.org/10.1111/j.1467-6486.2004.00450.x

Vandekerkhof, P., Steijvers, T., Voordeckers, W., \& Hendriks, W. (2011). Professionalization of TMT in Private Family Firms - the Danger of Institutionalism. Hasselt, Belgium.

Waldkirch, M., Melin, L., \& Nordqvist, M. (2017). When the Cure Turns Counterproductive: Parallel Professionalization In Family Firms. In Academy of Management Annual Meeting Proceedings. Academy of Management. https://doi.org/10.5465/ambpp.2017.50

Webster, J., \& Watson, R. T. (2002). Analyzing the Past to Prepare for the Future: Writing a Literature Review. MIS Quarterly, 26(2), 13-23.

Zhang, J., \& Ma, H. (2009). Adoption of professional management in Chinese family business: A multilevel analysis of impetuses and impediments. Asia Pacific Journal of Management, 26(1), 119-139. https://doi.org/10.1007/s10490-008-9099-y 